\title{
Satirising the bourgeois worldview: Patrick Hamilton's Impromptu in Moribundia
}

\author{
Neil Maycroft \\ History of Art \& Material Culture \\ Lincoln School of Art \& Design \\ University of Lincoln \\ e-mail: nmaycroft@lincoln.ac.uk
}

This paper was originally published as 'Satirising the bourgeois worldview: Patrick Hamilton's Impromptu in Moribundia', in Capital \&J Class: Special Issue on Cultural Production, Consumption and Resistance, No 84, October 2004. 


\begin{abstract}
As well as being a cultural product itself, literature provides a means for the critical interrogation of the processes of cultural production and consumption in class-structured capitalist society. Realist narrative, Utopian speculation and dystopian conjecture have all been used to good effect. So, too, have satire and fable, and these come together in a neglected and largely forgotten novel from 1939, Impromptu in Moribundia, ${ }^{1}$ written by the bourgeois Marxist Patrick Hamilton. Though dated in many ways, and clearly rooted in a particular social and political context, this fabulous tale, nevertheless, retains interest for those wishing to critique the production of the bourgeois cultural worldview. ${ }^{2}$
\end{abstract}

Patrick Hamilton emerged as a well-regarded author during the 1920s and 1930s and, in terms of subject, Hamilton wrote best about the social milieux of middle class southern England, in the voice of a bourgeois Marxist' (McKenna, 1994: 241). As such, he combined popular melodramatic stage thrillers such as Rope (1929) and Gaslight (1938) with specific radio plays and novels, which were often perceptive accounts of the alienation of life in the anonymous city (see B. Hamilton, 1972; Jones, 1991; French, 1993).

His work after this period is, however, hard to fully grasp without an appreciation of his conversion to Marxism, which occurred during the mid1930s. Hamilton accumulated a large Marxist library, though he never joined any communist party or engaged in significant activities apart from occasionally handing out communist literature. ${ }^{3}$ His was an isolated Marxism and his fiction reflects this lack of contact with the proletariat, especially in the sphere of production. In the sphere of consumption however, Hamilton's close observations, and his sympathies, were made manifest in his fiction. His characters inhabit a world of pubs, music halls, cafés, boarding houses

\footnotetext{
${ }^{1} \mathrm{~A}$ longer and expanded version of this review can be found in Maycroft (2003).

${ }^{2}$ However, according to one of Hamilton's biographers, writing about Impromptu in Moribundia, 'From the perspective of the 1990s [it] looks hopelessly dated' (Jones, 1991: 215). For another of his biographers, the book represents a 'dismal Stalinist tract' (French, 1993: 154). In this book and elsewhere, Hamilton certainly displayed a deluded faith in the Soviet Union, and a particularly fawning attitude towards Stalin.

${ }^{3}$ During the War Hamilton obtained the unlikely position of play-reader to the Soviet Embassy.
} 
and seaside resorts, and Hamilton is perceptive in his dissection of workingclass cultural preferences and 'consumption patterns'.

While Hamilton mainly preferred 'realist' narratives, characterised by characters' internal monologues and humorous set-pieces, his 1939 novel Impromptu in Moribundia broke radically with this approach. The book is a satirical fable, in which a nameless narrator is transported by means of a device called the 'Asteradio' to a distant planet, Moribundia, in which the worldview of the English bourgeoisie is made real. Moribundia is the "physical enactment of the stereotypes and myths of English middle-class culture and consciousness' (Widdowson, 1999: xi).

Hamilton's satire clearly attacks the view that one's life chances (standard of living, cultural opportunities and so on) are the result of meritocracy, the natural order of things, or simple hard work. Rather, his prime concern is to show that access to resources is the key factor in enabling successful courses of social and cultural action, and that these are structurally determined according to class position.

The bourgeois ideology of meritocracy, natural success and so on is literally made concrete in Moribundia in order to expose the fallacious nature of its foundations. So, for example, in Moribundia wealth is not created by labour, rather it is the moral qualities of 'virtue' and 'industry' which create wealth: 'Those who are virtuous and work hard, make money and get on; those who are bad and lazy, sink into lower social depths' (Hamilton, 1939/99: 95). Moreover, as 'the acquiring of money is simply a question of personal merit totally unrelated to any objective facts in the social scheme' (ibid: 95), there is no wage labour in Moribundia. Money simply 'comes' to people in proportion to their worth.

Despite the economic and social laws of Moribundian society, a clear class structure does exist, and it is a society in which characters concretise their class stereotypes at all levels and at all times. Drunken men, for example, are upper class, wear evening dress, slur their speech, have bright red noses and are watched benignly by friendly policemen. However, the class in charge of Moribundian society is the aristocracy, whose members are imbued with the seemingly benign colonial bearing of the perfect gentleman. Selfless, determined and sporting, this ruling class is honest, self-sacrificing and idealistic. The willowy and immaculate members of this class are physically contrasted 
to the squat and round-shouldered working or 'Gnikrow' class, ${ }^{4}$ who are all 'Yenkcoc' and are called Alf, Bert, Bill Juggins, Muggins or Sproggins, etc.

They also act according to the stereotypes promoted by the bourgeoisie of the time, including talking in comic-book cockney. The working class is not regarded as a social threat and is presented as an apolitical group of dismal non-aspirants -'Moribundian working man is utterly happy and contented' (ibid: 96)- who wants nothing more after a day's work than 'a pint of beer, a bit of a chat, a pipe or, perhaps, to take his Mrs. to the pictures' (ibid: 97).

Although materially well off, Moribundian workers keep coal in the bath, chop up grand pianos each week for firewood, and admit 'We're hopeless. We don't even try' (ibid: 148), as well as cheerily ripping people off, 'All we think of to-day is how we can avoid work, how we can scamp a job and get more money for it. There's not such a thing, any more, as honest pride in a job well done. We're thoroughly spoiled, that's what the matter is' (ibid: 148)..$^{5}$

The most pernicious class of all in Moribundia are the 'Little Men' of the middle class. These are the guardians of Moribundian society, identically dressed in suits and bowler hats and carrying rolled umbrellas which are used, on occasion, as weapons of moral enforcement. In a climactic scene, they hound the narrator out of Moribundia after a breach of class norms. The 'Little Men' here revert to the character that Hamilton regards as reflecting their true class nature. The Moribundian view, which sees them as 'harmless, helpful, friendly, tolerant, duty-doing little business-men' (Hamilton, 1939/1999: 182) gives way to 'cupidity, ignorance, complacence, meanness, ugliness, short-sightedness, cowardice, credulity, hysteria' (ibid: 182).

Despite mass unemployment and poverty, the 1930s was a decade in which the promotional industries of capitalism attempted to make big advances in the insinuation of consumerist values to the population as a whole. Hamilton found such promotional manoeuvres distasteful, and he lampoons them in Moribundia by taking them literally and making them real. Hamilton satirises many identifiable advertisements of the day by having his Mori-

\footnotetext{
${ }^{4}$ Hamilton uses the simple device of identifying the targets of critique by spelling them backwards.

${ }^{5}$ Many other members of the working class live indolently on the 'dole' in a life of luxury, a clear attack on the mass unemployment of the 1930s with its severe poverty, means test and so on.
} 
bundian characters extol the merits of particular commodities in the very language of the advertisements themselves.

The consumption of particular commodities brings about the exact effect, in the consumers, that their promotion promises. The narrator repeatedly gains favour with his Moribundian companion, Anne, by buying her "Siljoy Stockings, the ones with delicious silk thread which are so soft you can hardly feel them'. Conversely, non-consumption promises social disfavour, as Hamilton's narrator discovers when he encounters widespread public opprobrium for not keeping clean with 'Save-Life' soap. One interesting facet of this constant encouragement to consume, which Hamilton perceptively dismantles, is the colonisation of one's time which results from the increasing use of personal products as part of 'body maintenance routines'.

The narrator and Anne take a seaside holiday, during which the prospect of sexual congress is anticipated. However, each evening the narrator vainly waits in bed for Anne who, engaging in the seemingly endless consumption of beauty commodities, aims to increase her sexual allure. This leaves him so tired and disinterested that sexual contact is never even attempted. Hence, in Moribundia the consumption of commodities is made to coincide with the 'consumption' of life itself .Moribundians make themselves the physical manifestations of advertising ideology in other ways: young women who do not use products aimed at retaining their youth grow old and haggard prematurely; people with colds walk around with taps on their noses; and indigestion produces swathes of tiny devils, who proceed to poke one's stomach with forks. The narrator himself is literally chained to his bed with rheumatism for a lengthy period, until he consumes a miracle cure, 'Banishill Salts'. More striking is the Moribundian habit of speaking in the language of advertising clichés, through speech bubbles that appear in the air around them. In this sense, Moribundia itself can be seen as the commodity writ large, to the scale of a whole society. It is the realisation of bourgeois ideology as not simply an inverted view of the world, but as an inverted world itself. The technique of 'inversion' is used to reflect back to us a society organised along the lines of capitalist and bourgeois ideology made concrete. This theme of inversion finds a more subtle yet also more powerful expression in Hamilton's later novel, Hangover Square (1941). Using a contrivance whereby the book's central character is suffering from a form of schizophrenia, Hamilton produces a series of contrasting inversions of the world around him. The ability of the character to distinguish what is real and what is an illusion, caused 
by attacks of his 'dead moods', becomes progressively less certain, until the 'alienated' view of the world eventually becomes the rationally accepted one that disastrously guides the character's actions.

New Labour's trumpeting of meritocracy and enterprise as the foundations of both economic opportunity and life chances is marked. Similarly, the ideology of the 'classless' society is used to efface real class distinctions and structures of systemic inequality. The emphasis on consumption is even more marked in our society than in Moribundia.

Today, consumption is promoted as a prime leisure activity in itself, as well as as a way of marking social distinction. It is touted as an activity that promises physical, emotional and psychological satisfaction for all of our needs, both conscious and unconscious. Moreover, the so-called 'politics' of consumption that revolve around the construction of 'identities' and 'lifestyles' attests to the centrality of consumption in the form of consumerism. While people today may not explicitly use the language of advertisements, they do often turn themselves into walking advertisements for capitalist enterprises through the wearing of all manner of conspicuous labels, brands and logos.

On its publication in 1939, Impromptu in Moribundia did not sell well and was quickly forgotten, in comparison to Hamilton's other, more commercially popular work. However, taking the claims of the bourgeoisie seriously, and translating them into concrete social structures and relations, would be an interesting experiment today and, accordingly, much of Hamilton's vision in Impromptu in Moribundia remains relevant.

\section{References}

French, S. (1993) Patrick Hamilton: A Life. Faber \& Faber, London. Hamilton, B. (1972) The Light Went Out: The Life of Patrick Hamilton by his Brother Bruce Hamilton. Constable, London.

Hamilton, P. (1939/1999) Impromptu in Moribundia. Trent Editions, Nottingham.

Jones, N. (1991) Through a Glass Darkly: The Life of Patrick Hamilton. Scribners, London.

McKenna, B. (1994) 'Confessions of a heavy-drinking Marxist: Addiction in the work of Patrick Hamilton', in S. Vice, T. Campbell \& T. Armstrong 
(eds.) (1991) Beyond the Pleasure Dome: Writing and Addiction from the Romantics. Sheeld Academic Press.

McKenna, B. (1999) 'World upon world, genre and history: Patrick

Hamilton's 'Impromptu in Moribundia", in Utopian Studies, vol. 10, no. 1, pp. 69-85.

Maycroft, N. (2003) 'Hamilton's 'Impromptu in Moribundia", in Historical Materialism, vol. 10, no. 4, pp. 291-296.

Widdowson, P. J. (1978) 'The saloon bar society: Patrick Hamilton's ction in the 1930s', in J. Lucas (ed.) (1978) The 1930s: A Challenge to

Orthodoxy. Harvester Press, Sussex.

Widdowson, P. J. (1999) 'Introduction', in P. Hamilton (1939/1999)

Impromptu in Moribundia. Trent Editions, Nottingham. 